\title{
FORMA PISEMNA I ELEKTRONICZNA CZYNNOŚCI PRAWNYCH W PRAWIE CHIŃSKIM
}

$\mathrm{Na}$ gruncie polskiego prawa cywilnego, jak również wielu innych praw obcych, forma czynności prawnych jest rozumiana szeroko i oznacza każdy z możliwych sposobów przejawu woli. Obowiązuje przy tym zasada swobody formy oświadczenia woli. Nie ma ona jednak charakteru bezwzględnego, gdyż prawodawca lub same strony mogą wprowadzić od niej wyjątki, zastrzegając formę szczególną dla dokonania czynności prawnej.

Formami szczególnymi czynności prawnych są między innymi formy pisemna i elektroniczna. Pierwsza ma na świecie wielowiekową tradycję, jest znana od dawna i głęboko zakorzeniona w świadomości podmiotów prawa prywatnego. Druga jest natomiast dość nowa. Powstała bowiem dopiero w momencie stworzenia środków komunikacji elektronicznej na odległość, a jej obecny dynamiczny rozwój wiąże się z globalną ekspansją Internetu i dużą dostępnością urządzeń elektronicznych pozwalających na porozumiewanie się pomiędzy osobami będącymi w różnych miejscach.

Forma pisemna stanowi przy tym najbardziej powszechny sposób formalizowania stosunków cywilnoprawnych. Wynika to z przepisów ustaw zastrzegających wymóg jej zachowania dla dokonania określonych czynności prawnych, ale bardzo często również z woli samych podmiotów prawa cywilnego. Wśród części członków różnych społeczeństw panuje przy tym mylne przekonanie, że tylko umowa zawarta na piśmie jest ważna. W konsekwencji podmioty prawa cywilnego dokonują istotnych dla siebie czynności prawnych w formie pisemnej. Obecnie ze względu na globalny dynamiczny rozwój handlu elektronicznego wzrasta też znaczenie formy elektronicznej ${ }^{1}$.

\section{Forma pisemna czynności prawnych w prawie chińskim}

W prawie chińskim obowiąuje reguła swobody formy oświadczenia woli. W art. 56 zasad ogólnych prawa cywilnego Chińskiej Republiki Ludowej (General Principles of the Civil Law of the People's Republic of China - GPCL) ${ }^{2}$ z 1986 r. wskazano,

\footnotetext{
1 Artykuł opiera się na rozważaniach autorki zawartych w monografii: M. Maciejewska-Szałas, Forma pisemna i elektroniczna cåynności prawnych. Studium prawnoporównawcze, Warszawa 2014.

2 Wersja anglojęzyczna aktu normatywnego jest dostępna na stronie: http://www.npc.gov.cn/ englishnpc/Law/2007-12/12/content_1383941.htm (dostęp: 1.12.2016).
} 
że czynność prawna może zostać dokonana na piśmie, ustnie lub w innej formie. Tożsamą regułę przewidziano również w art. 10 prawa umów Chińskiej Republiki Ludowej (Contract Law of the People's Republic of China - CCL) ${ }^{3}$ z 1999 r. Zasada ta nie ma jednak charakteru bezwzględnego, gdyż ustawodawca dopuścił od niej wyjątki. W art. 56 GPCL podkreślono, że jeżeli prawo wymaga dokonania czynności prawnej w określonej formie, to należy spełnić ten warunek. Analogiczne rozwiązanie zastosowano na gruncie prawa zobowiązań, wskazując, że umowa powinna być zawarta na piśmie, gdy zastrzega to ustawa lub wymagają tego przepisy administracyjne oraz gdy strony tak postanowiły (art. $10 \mathrm{CCL}$ ).

\section{Zakres zastosowania formy pisemnej}

W różnych aktach normatywnych przewidziano obowiązek dokonania czynności prawnej na piśmie, wprowadzając niekiedy dodatkowy wymóg opatrzenia dokumentu podpisem lub pieczęcią przez strony. Przykładowo na piśmie musi zostać zawarta umowa: pożyczki sumy pieniężnej, z wyjątkiem sytuacji, gdy strony będące osobami fizycznymi postanowiły inaczej (art. 197 CCL), najmu na okres 6 miesięcy lub dłuższy (art. 215 CCL), leasingu finansowego (art. 238 CCL), o roboty budowlane (art. 270 CCL), o rozwój technologii (technology development contract) $)^{4}$ (art. 330 CCL), o przeniesienie technologii (technology transfer contract) (art. 342 CCL) ${ }^{5}$, hipoteki (art. 185 Property Law of the People's Republic of China z 2007 r. - PLC) ${ }^{6}$ oraz zastawu (art. 210 PLC). Nadto, przedsiębiorca składowy jest zobowiązany podpisać lub opieczętować kwit składowy wydawany składającemu (art. 386 CCL). Umowa spółki z ograniczoną odpowiedzialnością powinna również zostać opatrzona podpisem bądź pieczęcia przez każdego ze wspólników (art. 25 Company Law of the People's Republic of China) ${ }^{7}$. Tożsamy obowiązek nałożono na wystawcę dokumentu obrotowego (negotiable instrument), w tym weksla i czeku (art. 4 Negotiable Instruments Law of the People's Republic of China - NIL) ${ }^{8}$, jak również na mocodawcę, w przypadku gdy przepis szczególny wymaga udzielenia pełnomocnictwa na piśmie (art. 65 GPCL).

3 Wersja anglojęzyczna aktu normatywnego jest dostępna na stronie: http://www.npc.gov.cn/ englishnpc/Law/2007-12/11/content_1383564.htm (dostęp: 1.12.2016).

4 Przedmiotem technology development contract jest rozwój nowej technologii, produktu, techniki, tworzywa oraz związanego z nimi systemu (art. 330 CCL).

5 Technology transfer contract obejmuje umowy o przeniesienie: patentu, prawa wynikającego ze zgłoszenia patentowego, tajemnic technicznych, licencji na korzystanie z patentu (art. 342 CCL).

6 Wersja anglojęzyczna aktu normatywnego jest dostępna na stronie: http://www.npc.gov.cn/ englishnpc/Law/2009-02/20/content_1471118.htm (dostęp: 1.12.2016).

Wersja anglojęzyczna aktu normatywnego jest dostępna na stronie: http://www.npc.gov.cn/ englishnpc/Law/2007-12/13/content_1384124.htm (dostęp: 1.12.2016).

8 Wersja anglojęzyczna aktu normatywnego jest dostępna na stronie: http://www.npc.gov.cn/ englishnpc/Law/2007-12/12/content_1383718.htm (dostęp: 1.12.2016). 
Prawodawca chiński wprowadził wymóg formy pisemnej także na gruncie prawa spadkowego. Przykładowo dopuszczalne jest zarówno sporządzenie testamentu notarialnego (notarial will), jak i własnoręcznego (testator written will). Ten ostatni polega na tym, że testator spisuje swoją wolę własnoręcznie, następnie ją podpisuje, ma też obowiązek podać datę dokonania czynności. Prawo dopuszcza również testament sporządzony w imieniu rozporządzającego majątkiem na wypadek śmierci w obecności dwóch lub większej liczby świadków, z których jeden spisuje jego treść, datuje i podpisuje, po czym dokument opatruje podpisem drugi świadek lub świadkowie oraz testator (art. 17 Law of Succession of the People's Republic of China z 1985 r.) ${ }^{9}$.

\section{Pojęcie pisma i podpisu}

Prawodawca chiński przewidział definicję legalną terminu pismo w art. 11 CCL. Oznacza ono memorandum umowy, list, wiadomość elektroniczną (włączając telegram, teleks, faksymile, elektroniczną wymianę danych oraz pocztę elektroniczna) itp., które są zdatne do wyrażenia zawartej w nich treści w formie materialnej. Przyjęta definicja jest szeroka, gdyż obejmuje zarówno tradycyjne pismo, jak i zapis elektroniczny.

W prawie chińskim nie wprowadzono natomiast ogólnej definicji terminu podpis. Akty normatywne zasadniczo nie wyjaśniają znaczenia tego pojęcia ${ }^{10}$. Wyjątek stanowi jedynie art. 7 NIL, wskazujący, że słowa podpis i pieczęć na dokumencie obrotowym oznaczaja, po pierwsze, podpis albo pieczęć bądź, po drugie, podpis i pieczęć. Ponadto stwierdzono, że sygnatariusz powinien podpisać się swoim prawdziwym nazwiskiem. W opinii Ludowego Sądu Najwyższego (Supreme People’s Court) z dnia 11 października 1985 r., wydanej na gruncie prawa spadkowego, wymóg podpisu odnosi się do własnoręcznego napisania przez osobę jej nazwiska ${ }^{11}$.

Przepisy prawa chińskiego wprowadzające warunki formalne charakteryzują się tym, że z reguły zastrzegają opatrzenie pisma podpisem albo pieczęcią ${ }^{12}$, pozostawiając decyzję w tej kwestii stronie czynności prawnej. Prawodawca stawia wówczas podmiot przed alternatywa podpisania bądź opieczętowania dokumentu. Wydaje się bowiem, że w prawie chińskim znak odbity z pieczęci jest uznawany za ekwiwalent nazwiska napisanego własnoręcznie przez sygnatariusza ${ }^{13}$. Może to być uzasadnione faktem, że pieczętowanie stanowi w Chinach sposób uwierzy-

\footnotetext{
9 Wersja anglojęzyczna aktu normatywnego jest dostępna na stronie: http://www.fmprc.gov. cn/ce/cgny/eng/lsqz/laws/t42224.htm (dostęp: 1.12.2016).

10 M. Wang, The impact of information technology development on the legal concept: a particular examination on the legal concept of ,, signatures”, „International Journal of Law \& Information Technology” 2007, vol. 15 , no. 3 , s. 260.

11 Ibidem, s. 261.

12 Tak m.in. w art. 32, 386 CCL, art. 4 NIL, art. 65 GPCL, art. 25 Company Law of the People's Republic of China.

13 M. Wang, The impact..., s. 261.
} 
telnienia dokumentu, mający bardzo długą tradycję. Niekiedy przepisy wymagaja zarówno złożenia podpisu, jak i przystawienia pieczęci. W praktyce dokumenty są często sygnowane własnoręcznie przez podmioty oraz opatrywane pieczęcią osoby prawnej lub innej jednostki organizacyjnej nawet wówczas, gdy żadna norma tego nie zastrzega ${ }^{14}$.

Z samej definicji pisma, jak również z przepisów zasad ogólnych prawa cywilnego Chińskiej Republiki Ludowej oraz prawa umów Chińskiej Republiki Ludowej nie wynika generalny obowiązek opatrzenia go podpisem. W konsekwencji, aby spełnić wymóg dokonania czynności prawnej na piśmie, nie jest konieczne jego sygnowanie przez strony. Jak już wyżej wskazano, przedmiotowemu pojęciu nadano na gruncie prawa umów bardzo szerokie znaczenie, gdyż obejmuje ono obok tradycyjnego pisma również zapis elektroniczny. W rezultacie wymóg dokonania czynności prawnej na piśmie strony moga spełnić, przesyłając sobie nawzajem niepodpisane oświadczenia woli za pomoca telegrafu, teleksu, faksu czy też poczty elektronicznej.

Prawodawca chiński wprowadził obowiązek złożenia podpisu lub przystawienia pieczęci w art. 32 CCL dotyczącym tylko jednego rodzaju pisma, tj. memorandum umowy, oraz w przepisach szczególnych normujących dokonanie określonych czynności prawnych (np. art. 65 GPCL, art. 4 NIL, art. 25 Company Law, art. 17 Succession Law). W tym pierwszym przypadku, gdy strony zawierają umowę za pomoca memorandum kontraktu, dochodzi ona do skutku z chwila jego podpisania lub opieczętowania przez strony.

\section{Skutki niedochowania formy pisemnej}

Ustawodawca chiński zastrzegł dokonanie czynności prawnych w formie pisemnej pod różnymi rygorami, w tym nieważności oraz dla wywołania określonych skutków prawnych. Niedopełnienie warunków formalnych nie zawsze jednak powoduje ich bezskuteczność. Przykładowo, na gruncie prawa zobowiązań, jeśli z ustawy, przepisów administracyjnych lub porozumienia stron wynika, że umowa powinna być zawarta na piśmie, a strony nie uczyniły zadość temu wymogowi, lecz jedna z nich spełniła swoje główne świadczenie, a druga je przyjęła, to umowa została zawarta (art. 36 CCL). Tożsame rozwiązanie zastosowano odnośnie do memorandum umowy, gdy jeden z kontrahentów wykonał swój główny obowiązek, a drugi go zaakceptował przed podpisaniem albo opieczętowaniem pisma (art. 37 CCL) ${ }^{15}$.

\footnotetext{
14 Ibidem, s. 261.

15 W systemach common law podobny skutek osiaga się w rezultacie zastosowania przez sądy equity doktryny częściowego wykonania (doctrine of part performance).
} 
Forma elektroniczna czynności prawnych w prawie chińskim

Uchwalenie aktów prawnych normujących
podpis elektroniczny i zapis elektroniczny

Pierwsze akty prawne normujące jeden rodzaj podpisu elektronicznego, tj. podpis cyfrowy, jak również podmioty świadczące usługi certyfikacyjne oraz Infrastrukturę Klucza Publicznego, uchwalono w poszczególnych miastach i prowincjach chińskich. Przykładowo w Szanghaju władze komunalne wydały w 2000 r. zarządzenie, na mocy którego stworzyły spółkę municypalną Shanghai Electronic Certificate Authority Center Co. Ltd., powołaną do wystawiania certyfikatów cyfrowych, weryfikacji tożsamości osób ubiegających się o nie oraz przyznawania innym osobom prawnym statusu urzędu certyfikacji ${ }^{16}$.

W sierpniu 2001 r. prowincja Hainan jako pierwsza przyjęła akt prawny zatytułowany Środki tymczasowe dotyczące administracji usług poświadczania certyfikatów cyfrowych (Interim Measures for the Administration of the Certification of Digital Certificates) normujący przedmiotowa problematykę. Powołano w nim specjalną instytucje o nazwie Information Industry Administration, której zadaniem było regulowanie i nadzorowanie działalności podmiotów świadczących usługi certyfikacyjne. W akcie zdefiniowano też podstawowe terminy, w tym dokument elektroniczny, podpis cyfrowy, certyfikat cyfrowy, jak również przewidziano procedurę uzyskania licencji przez urząd certyfikacji, wskazano wykonywane przez niego usługi i ponoszoną odpowiedzialność oraz obligatoryjną treść certyfikatu ${ }^{17}$. Z kolei w grudniu 2002 r. władze prowincji Guangdong przyjęły Ordinance on Electronic Transactions normujący kwestie podpisu elektronicznego oraz podmiotów świadczących usługi certyfikacyjne. Stworzyły również publiczny, prowincjonalny urząd certyfikacji o nazwie Guangdong Electronic Certification Authority ${ }^{18}$.

Ustawa o podpisach elektronicznych Chińskiej Republiki Ludowej (Electronic Signatures Law of the People's Republic of China - ESL) ${ }^{19}$, regulująca w skali całego państwa problematykę podpisu elektronicznego, podmiotów świadczących usługi certyfikacyjne oraz PKI, została uchwalona dnia 28 sierpnia 2004 r., z mocą obo-

\footnotetext{
16 S. Blythe, China's New Electronic Signature Law and Certification Authority Regulations: A Catalyst for Dramatic Future Growth of E-Commerce, „Chicago-Kent Journal of Intellectual Property” 2007, vol. 7, issue 1, s. 12. Szerzej na ten temat: I. Rambarran, I Accept, But Do They:... The Need for Electronic Signature Legislation on Mainland China, „Transnational Lawyer”, Spring 2002, vol. 15, Issue 2, s. $428-429$.

17 S. Blythe, China's New Electronic Signature Law..., s. 12-13.

18 Ibidem, s. 13.

19 Wersja anglojęzyczna aktu normatywnego jest dostępna na stronie: http://www.npc.gov.cn/ englishnpc/Law/2007-12/05/content_1381960.htm (dostęp: 1.12.2016).
} 
wiązująca od 1 kwietnia 2005 r. Akt składa się z pięciu rozdziałów zatytułowanych: Przepisy ogólne, Wiadomości elektroniczne, Podpisy elektroniczne i certyfikacja, Odpowiedzialność prawna oraz Przepisy uzupełniające. Na podstawie delegacji zawartej w art. 25 ustawy Ministerstwo Przemysłu Technologii i Informacji (Ministry of Industry and Information Technology - MII) wydało w dniu 28 stycznia 2005 r. akt wykonawczy o nazwie Certification Authority Regulations (CAR ${ }^{20}$, w którym w sposób szczegółowy unormowano procedurę uzyskania licencji przez urzędy certyfikacji, jak również świadczone przez nie usługi oraz ponoszoną odpowiedzialność.

Spełnienie wymogu pisma przez zapis elektroniczny

Prawodawca chiński posłużył się w ustawie terminem wiadomość elektroniczna (data message), który zdefiniował, wzorując się na art. 2 lit. a ustawy modelowej UNCITRAL o handlu elektronicznym z dnia 12 czerwca 1996 r. $^{21}$ (UNCITRAL Model Law on Electronic Commerce - MLEC), jako informację utworzona, przesłana, odebraną lub przechowywaną za pomocą elektronicznych, optycznych, magnetycznych bądź innych podobnych środków (art. 2 ESL). Z powyższego wynika, że przedmiotowemu pojęciu nadano szerokie znaczenie. Wydaje się, że obejmuje ono wszystkie rodzaje wiadomości utworzonych, wysłanych, otrzymanych lub przechowywanych w formie innej niż papierowa, i to zarówno tych, które zostały przesłane w związku z dokonaniem transakcji elektronicznej, jak i tych nieprzeznaczonych do komunikacji ${ }^{22}$. W przytoczonej definicji legalnej nie zawarto wprawdzie przykładowego wyliczenia wiadomości elektronicznych, jednak uczyniono to w art. 11 CCL, w którym ustalono znaczenie terminu pismo na gruncie prawa umów, wskazując, że wiadomością elektroniczna jest telegram, teleks, faksymile, elektroniczna wymiana danych oraz poczta elektroniczna.

Prawny wymóg pisma spełnia zapis elektroniczny, jeżeli wiadomość elektroniczna jest zdatna do przedstawienia swojej treści w formie materialnej oraz można ja odtwarzać, konsultować i używać w każdym czasie (art. 4 ESL). Jak wyżej wskazano, terminowi pismo nadano szerokie znaczenie, obejmujące także zapis elektroniczny, już w art. 11 CLC, jednakże wprowadzenie zasady równoważności do ustawy o podpisach elektronicznych było niezbędne ze względu na ograniczony zakres zastosowania tego pierwszego aktu normatywnego. Obecnie bowiem wymóg pisma statuowany w jakimkolwiek przepisie, z wyjątkiem wyłączonych na podsta-

20 Order No. 35 of Ministry of Information Industry People's Republic of China, promulgated 28 January 2005, effective 1 April 2005.

21 Tekst w języku angielskim i francuskim opublikowano w raportach UNCITRAL, Dokumenty oficjalne Zgromadzenia Ogólnego ONZ, Suplement nr 17 (A/50/17) oraz Suplement nr 17 (A/51/17), Nowy Jork 1995-1996.

22 W. Yan, The Electronic Signatures Law: China's First National E-Commerce Legislation, „Intelectuall Property \& Technology Law Journal”, June 2005, vol. 17, issue 6, s. 6. 
wie art. 3 ESL, może zostać spełniony przez zapis elektroniczny czyniący zadość przesłankom przewidzianym w art. 4 ustawy. Pierwszy warunek, tj. że wiadomość elektroniczna musi być zdatna do przedstawienia swojej treści w formie materialnej, zaczerpnięto z art. 11 CCL. Natomiast drugi, stanowiący, że winna być tak sporządzona, by można ją było odtwarzać, konsultować oraz używać w każdym czasie, stanowi novum $\mathrm{w}$ prawie chińskim, nawiązując częściowo do rozwiązania przyjętego w art. 6 MLEC i art. 9 ust. 2 Konwencji Narodów Zjednoczonych o używaniu komunikacji elektronicznej w międzynarodowych kontraktach z 23 listopada 2005 r. (United Nations Convention on the Use of Electronic Communications in International Contracts - CUECIC ${ }^{23}$. Wydaje się, że prawodawca chiński powinien usunąć rozbieżności pomiędzy przesłankami, które należy spełnić na gruncie prawa umów i ustawy o podpisach elektronicznych, by uczynić zadość wymogowi pisma, przez dodanie drugiego warunku do treści art. 11 CCL, ponieważ jego realizacja zapewnia dysponentowi wiadomości elektronicznej możliwość ponownego zapoznania się z jej treścią i korzystania z niej, co jest istotne dla stron zawierających umowę.

\section{Spełnienie wymogu podpisu przez podpis elektroniczny}

Termin podpis elektroniczny oznacza dane elektroniczne zawarte lub dołączone do wiadomości elektronicznej, które są wykorzystywane do identyfikacji podpisującego oraz wskazania zaaprobowania przez niego jej treści (art. 2 ESL). Przytoczoną definicję legalną wzorowano na art. 2 lit. a ustawy modelowej UNCITRAL o podpisach elektronicznych z 5 lipca 2001 r. (A/CN.9/493) (UNCITRAL Model Law on Electronic Signatures - MLES), jest ona zatem technologicznie neutralna. Nadto zastosowano podejście funkcjonalnej równoważności, wymagając, by podpis elektroniczny spełniał dwie podstawowe funkcje tradycyjnego podpisu, tj. identyfikacji sygnatariusza oraz wskazania zaaprobowania przez niego treści wiadomości elektronicznej.

Prawodawca chiński, wzorując się na MLES i dyrektywie 1999/93/WE Parlamentu Europejskiego i Rady w sprawie wspólnotowych ram w zakresie podpisów elektronicznych z 13 grudnia 1999 r. (Dz. Urz. WE L 13 z 19.01.2000 r., s. 12), wprowadził kwalifikowaną postać podpisu elektronicznego, który określił mianem niezawodnego (reliable). Powinien on łącznie spełniać następujące przesłanki: po pierwsze, w momencie, gdy dane służące do stworzenia podpisu elektronicznego są używane, stanowią one własność sygnatariusza, po drugie, w momencie podpisywania są one kontrolowane wyłącznie przez niego, po trzecie, każda zmiana dokonana w podpisie elektronicznym po jego złożeniu jest wykrywalna, po czwarte, każda zmiana treści i formy wiadomości elektronicznej po jej sygnowaniu jest wykrywalna (art. 13 ESL). Powołane wymogi sformułowano w sposób technologicznie neutral-

${ }^{23}$ Tekst w wersji anglojęzycznej jest dostępny na stronie: http://www.uncitral.org (dostęp: 1.12.2016). 
ny, jednak w rzeczywistości może je spełnić jedynie podpis cyfrowy ${ }^{24}$ bądź podpis mobilny będący jego szczególnym rodzajem.

Prawodawca chiński zezwolił wszak na korzystanie z podpisów elektronicznych czyniących zadość warunkom niezawodności ustalonym samodzielnie przez zainteresowane strony (art. 13 ESL).

W art. 14 ESL wprowadzono zasadę równoważności, wskazując, że niezawodny podpis elektroniczny ma taką samą ważność i skuteczność jak podpis własnoręczny lub znak odbity z pieczęci. Prawny wymóg podpisu można zatem spełnić, sygnując oświadczenie niezawodnym podpisem elektronicznym.

\section{Zasada niedyskryminacji wiadomości elektronicznej \\ i podpisu elektronicznego}

Dokonywanie czynności prawnych w formie elektronicznej zależy wyłącznie od woli podmiotów prawa. Wyraźnie bowiem zastrzeżono, że osoby podejmujące działania na gruncie prawa cywilnego, w szczególności strony zawierające umowy, moga wyrazić zgodę na posługiwanie się podpisami elektronicznymi i wiadomościami elektronicznymi bądź jej nie udzielić (art. 3 ESL). Natomiast w przypadku, gdy kontrahenci przystali na korzystanie z nich, nie moga następnie odmówić im ważności wyłącznie na tej podstawie, że mają one formę elektroniczną (art. 3 ESL).

Zapis i podpis elektroniczny mogą stanowić dowód w postępowaniu przed sadem lub innym organem władzy publicznej. W art. 7 ESL wyraźnie bowiem zastrzeżono, że nie można odmówić uwzględnienia wiadomości elektronicznej w materiale dowodowym sprawy tylko na tej podstawie, że do jej stworzenia, przesłania, odebrania lub przechowywania posłużono się elektronicznym, optycznym, magnetycznym bądź innym podobnym środkiem. Nadto wskazano, że dokonując oceny jej autentyczności i wiarygodności jako dowodu w postępowaniu, należy wziąć pod uwage niezawodność metody, która została użyta do jej stworzenia, przechowywania lub przekazania oraz do zachowania jej integralności i identyfikacji nadawcy, a także inne istotne czynniki (art. 8 ESL).

W dotychczasowym orzecznictwie sądów chińskich wydano niewiele wyroków rozstrzygających spory dotyczące podpisów elektronicznych. Istnieją również pewne wątpliwości co do mocy dowodowej dokumentów elektronicznych ${ }^{25}$. Przykładowo w sprawie Shanghai 'Rong-Shu-Xia' Computer Ltd. przeciwko China Society Publisher ${ }^{26}$

24 A. Srivastava, No Rice, No Wife To Cook: An Analysis of the Electronic Signatures Law of China, „International Journal of Law and Information Technology”, Autumn 2005, vol. 13, issue 3, s. 440; M. Wang, M. Wang, Introduction to the Electronic Signatures Law of People's Republic of China, „Digital Evidence \& Electronic Signature Law Review” 2005, vol. 2, s. 80.

25 M. Wang, The impact..., s. 262-263.

26 Shanghai 'Rong-Shu-Xia' Computer Ltd. v. China Society Publisher, The First Intermediate People's Court in Beijing, December 2000. 
z 2000 r. sąd orzekł, że e-mail może zgodnie z art. 11 CLC stanowić dowód w postępowaniu, jednak przedstawione przez stronę wiadomości z poczty elektronicznej zostały odrzucone z uwagi na wątpliwości co do ich autentyczności ${ }^{27}$.

Z kolei w sprawie Beijing Han-Hua-Kai-Jie Technology development Ltd. przeciwko Chen sąd uznał e-mail za autentyczny, a w konsekwencji za wiarygodny dowód, gdyż pozwany Chen, będący jego nadawcą, był z zawodu inżynierem zajmującym się oprogramowaniami, stąd miał wiedzę i umiejętności niezbędne do zapewnienia bezpieczeństwa swojej poczcie elektronicznej ${ }^{28}$.

W sprawie Yang Chunning przeciwko Han Ying ${ }^{29}$ z 2005 r. orzeczono natomiast, że wiadomość tekstowa (mobile text message) przesłana telefonem komórkowym została opatrzona podpisem elektronicznym i stanowi dowód w postępowaniu sądowym ${ }^{30}$.

Z kolei w postępowaniu cywilnym prowadzonym na skutek wniesienia pozwu przez Zhang Hua przeciwko Shanghai Danwei Information Consultation Co. Ltd. o zapłatę premii i rekompensatę sąd poprosił Wydział Nadzoru nad Bezpieczeństwem Informacji w Internecie (Department Information Internet Security Supervision) Policji Metropolitalnej Szanghaju o zweryfikowanie autentyczności pięciu e-maili wysłanych osobom nieuprawnionym, a zawierających poufne dane dotyczace pozwanego przedsiębiorstwa ${ }^{31}$. Po dokonaniu analizy technicznej ustalono, że przesłano je z konta poczty elektronicznej Zhang Hua. Sąd, przypisawszy na podstawie opinii policji i zeznań świadków wysłanie e-maili powodowi, oddalił pozew wyrokiem z dnia 11 maja 2009 r., gdyż ujawnienie informacji poufnych stanowiło naruszenie postanowień umowy o pracę i pozbawiło go prawa do premii ${ }^{32}$.

Podmiot świadczący usługi certyfikacyjne, podpisujący oraz strona polegająca na podpisie elektronicznym

W Chinach usługi certyfikacyjne mogą świadczyć wyłącznie urzędy certyfikacyjne, którym MII udzieliło stosownej licencji. Osoba zainteresowana jej uzyskaniem skła-

27 M. Wang, Case Note: People's Republic of China, „Digital Evidence \& Electronic Signature Law Review" 2007, vol. 4, s. 95, M. Wang, The impact..., s. 263; M. Wang, Electronic Evidence in China, „Digital Evidence \& Electronic Signature Law Review” 2008, vol. 5, s. 49.

28 M. Wang, The impact..., s. 263; M. Wang, Electronic Evidence..., s. 49.

29 Yang Chunning v. Han Ying, 2005 Hai Min Chu Zi NO.4070, Beijing Hai Dian District People's Court.

30 M. Wang, The impact..., s. 263; M. Wang, Electronic Evidence..., s. 49-50; Ch. Jihong, Chinese Digital Evidence Law Overview and Suggestions for Multinational Enterprises, „Digital Evidence \& Electronic Signature Law Review” 2009, vol. 5, s. 209.

31 Zhang Hua v. Shanghai Danwei Information Consultation Co. Ltd, Shanghai People's Court of Jing'an District.

32 M. Wang, Case Note: China..., „Digital Evidence \& Electronic Signature Law Review” 2009, vol. 6, s. 275-276. 
da wniosek oraz dokumenty wskazujące na spełnienie warunków przewidzianych w art. 17 ESL. Wydanie pozwolenia na świadczenie usług certyfikacyjnych uzależniono bowiem od wykazania, że, po pierwsze, podmiot zatrudnia profesjonalnych techników i kadrę zarządzającą posiadających kwalifikacje do wykonywania tego rodzaju działalności, po drugie, ma odpowiedni kapitał i lokale, po trzecie, dysponuje technologią i urządzeniami czyniącymi zadość krajowym normom bezpieczeństwa, po czwarte, przedstawia dokument zawierający zezwolenie na szyfrowanie danych wydany przez Departament Tajemnic Państwowych oraz spełnia inne wymagania statuowane we właściwych przepisach, w tym w Certification Authority Regulations, który jest aktem wykonawczym do ustawy ${ }^{33}$.

MII podejmuje decyzję w terminie 45 dni od daty złożenia wniosku i dokumentów, po dokonaniu oceny ich zgodności z prawem oraz uzyskaniu opinii odpowiednich departamentów, w tym handlu. Skutkiem pozytywnego rozpatrzenia sprawy jest wydanie podmiotowi licencji na świadczenie usług certyfikacyjnych. O odmowie udzielenia pozwolenia MII informuje wnioskodawcę na piśmie, w którym podaje przyczyny podjęcia takiej decyzji (art. 18 ESL).

Na podstawie licencji urząd certyfikacji uzyskuje wpis we właściwym rejestrze ${ }^{34}$. Podmiot świadczący usługi certyfikacyjne publikuje szczegółowe informacje, w tym swoją nazwę, siedzibę, numer i datę wydania oraz okres ważności licencji, jak również preferowane sposoby zawierania umów na prowadzonej przez siebie stronie internetowej (art. 18 ESL, art. 12 CAR). Jednocześnie przygotowuje zasady certyfikacji elektronicznej (electronic certification rules), obejmujące reguły i procedury, według których będzie prowadził działalność, po czym ogłasza je w Internecie i przesyła do MII (art. 19 ESL).

W art. 16 ESL zastrzeżono, że w przypadku, gdy wymagane jest, by podpis elektroniczny certyfikowała osoba trzecia, taką usługę może wykonać wyłącznie ustanowiony zgodnie z prawem urząd certyfikacji. W przepisie nie wskazano jednak podmiotu uprawnionego do nałożenia takiego obowiązku. Wydaje się, że może on wynikać z umowy zawartej przez strony lub ze szczególnej normy prawnej.

$\mathrm{Na}$ gruncie ustawy podpisującym jest osoba będąca właścicielem danych służących do stworzenia podpisu elektronicznego, która składa go w imieniu własnym lub podmiotu przez nią reprezentowanego (art. 34 ust. 1 ESL). Stroną polegająca na podpisie elektronicznym jest natomiast osoba, która angażuje się w określoną czynność, działając w zaufaniu do certyfikatu bądź podpisu elektronicznego (art. 34 ust. 2 ESL).

Dane służące do stworzenia podpisu elektronicznego oznaczają z kolei takie dane, jak symbole, liczby itp. wykorzystywane w procesie składania podpisu elektronicznego, które w sposób niezawodny łączą go z sygnatariuszem (art. 34 ust. 4 ESL).

33 Ch. Zhang, L. Lingfei, The Chinese Approach to Electronic Transactions Legislation, „Computer Law Review \& Technology Journal”, Winter 2005, vol. 9, issue 2, s. 349.

34 S. Blythe, China's New Electronic Signature Law..., s. 18. 
Natomiast dane służące do weryfikacji podpisu elektronicznego zdefiniowano jako dane wykorzystywane do weryfikacji podpisu elektronicznego, w tym kody, hasła, algorytmy lub klucze publiczne itd. (art. 34 ust. 5 ESL).

Podpisujący może wystąpić do podmiotu świadczącego usługi certyfikacyjne z wnioskiem o wydanie certyfikatu będącego wiadomością elektroniczną bądź innym zapisem elektronicznym, który uwierzytelnia związek istniejący pomiędzy sygnatariuszem a danymi służącymi do stworzenia podpisu elektronicznego (art. 34 ust. 3 ESL). Na wnioskodawcę nałożono przy tym obowiązek podania prawdziwych, kompletnych i dokładnych informacji wymaganych przez urząd certyfikacji (art. 20 ESL). Niewykonanie go skutkuje powstaniem odpowiedzialności za szkodę poniesiona przez stronę polegającą na podpisie elektronicznym lub podmiocie świadczącym usługi certyfikacyjne (art. 27 ESL). Wystawca certyfikatu jest zobowiązany do ustalenia tożsamości wnioskodawcy i dokonania oceny przedstawionych przez niego danych (art. 15 ESL).

Certyfikat powinien być dokładny i bezbłędny oraz wskazywać: nazwę jego wystawcy, nazwisko właściciela, numer seryjny i okres ważności, dane służące do weryfikacji podpisu elektronicznego sygnatariusza, jak również podpis elektroniczny podmiotu świadczącego usługi certyfikacyjne oraz inne informacje określone przez MII.

Urząd certyfikacji gwarantuje kompletność i ścisłość treści certyfikatu w okresie jego ważności oraz zapewnia stronie polegającej na podpisie elektronicznym możliwość weryfikacji informacji w nim zawartych oraz innych istotnych kwestii (art. 22 ESL). Nadto, przez co najmniej 5 lat po wygaśnięciu certyfikatu przechowuje dane z nim związane (art. 24 ESL).

Podpisujący ma obowiązek należycie zabezpieczyć dane służące do stworzenia podpisu elektronicznego przed ich ujawnieniem. Jeśli dowie się, że przestały one być tajne lub mogło to nastapić, powinien niezwłocznie poinformować o tym fakcie zainteresowane strony oraz zaniechać ich dalszego wykorzystywania (art. 15 ESL). Niewykonanie wskazanych obowiązków rodzi odpowiedzialność za szkodę poniesiona przez osobę polegająca na podpisie elektronicznym bądź podmiocie świadczacym usługi certyfikacyjne (art. 27 ESL).

Licencjonowany urząd certyfikacji jest natomiast odpowiedzialny za szkodę doznaną przez sygnatariusza lub stronę polegającą na podpisie elektronicznym przy angażowaniu się w czynności podejmowane na gruncie prawa cywilnego w następstwie działania w zaufaniu do świadczonej przez niego usługi, chyba że wykaże on brak winy (art. 28 ESL) ${ }^{35}$. W przedmiotowej ustawie uregulowano również skutki wykonywania usług certyfikacyjnych bez uzyskania licencji (art. 29 ELS), niedopełnienia obowiązków informacyjnych (art. 30 ELS), nieprzestrzegania zasad certyfikacji elektronicznej oraz przepisów prawa (art. ESL).

35 Ch. Zhang, L. Lingfei, The Chinese Approach..., s. 351. 
Ustawa o podpisach elektronicznych ma dość szeroki zakres zastosowania, gdyż dotyczy wszystkich dokumentów sporządzanych przez podmioty prawa, z wyjątkiem tych odnoszących się do małżeństwa, adopcji, dziedziczenia i innych relacji osobistych, jak również przeniesienia praw i interesów do nieruchomości, w tym gruntu, budynku itp. oraz zawieszenia świadczenia usług użyteczności publicznej, jak np. dostaw wody, ciepła, gazu, elektryczności. Dodatkowe wyłączenia mogą zostać przewidziane w przepisach szczególnych, jeśli posługiwanie się dokumentami elektronicznymi byłoby w określonym przypadku niewłaściwe (art. 3 ESL) ${ }^{36}$.

\section{Podsumowanie}

$\mathrm{Na}$ gruncie prawa chińskiego obowiązuje reguła dowolności formy oświadczenia woli. Prawodawca wprowadził jednak od niej wyjątki, zastrzegając dokonanie określonych czynności prawnych na piśmie oraz przewidując niekiedy dodatkowy wymóg opatrzenia dokumentu podpisem lub pieczęcią przez strony.

Pojęciu pisma nadano szerokie znaczenie. Oznacza ono bowiem memorandum umowy, list, wiadomość elektroniczną (włączając telegram, teleks, faksymile, elektroniczną wymianę danych oraz pocztę elektroniczna) itp., które są zdatne do wyrażenia zawartej w nich treści w formie materialnej, a więc termin ten obejmuje zarówno językowe znaki graficzne napisane na papierze, jak i zapis elektroniczny. Ustawodawca nie przewidział natomiast definicji podpisu, wszak zasadniczo jest nim nazwisko napisane własnoręcznie na dokumencie przez sygnatariusza. Przepisy prawa chińskiego charakteryzują się też tym, że wprowadzają obowiązek podpisania albo opieczętowania pisma, znak odbity z pieczęci stanowi więc ekwiwalent nazwiska skreślonego ręcznie przez podpisującego.

Wymóg dokonania czynności prawnej na piśmie lub dodatkowo opatrzenia go podpisem bądź pieczęcią zastrzeżono pod różnymi rygorami, w szczególności zaś ad solemnitatem oraz ad eventum. Przepisy prawa przewidują konstrukcje osłabiające rygor nieważności.

Wymóg pisma spełnia zapis elektroniczny, gdy wiadomość elektroniczna jest zdatna do przedstawienia swojej treści w formie materialnej oraz można ją odtwarzać, konsultować i używać jej w każdym czasie. Z kolei warunkowi formalnemu złożenia podpisu lub przystawienia pieczęci czyni zadość niezawodny podpis elektroniczny, tj. spełniający surowe przesłanki przewidziane w prawie. Zasada równoważności nie ma jednak charakteru bezwzględnego, gdyż prawodawca dopuścił od niej wyjątki.

36 A. Srivastava, No Rice..., s. 439; W. Yan, The Electronic Signatures..., s. 6, 10; M. Wang, M. Wang, Introduction to the Electronic Signatures..., s. 80-81. 


\section{SUMMARY}

\section{THE WRITTEN AND ELECTRONIC FORMS OF LEGAL ACTS IN CHINESE LAW}

The article presents and analyzes the problem of forms of legal acts, especially contracts, in Chinese law. Chinese law provides for freedom as to the form of a declaration of intent. This freedom is not absolute, however, for the legislator has allowed for certain exceptions. The law provides for written form of contracts and electronic form of contracts. The article presents the scope of written form, the legal definitions of the terms "writing", "signature" and "seal" and finally, how to fulfill requirements of written form of contracts. It also introduces a short history of passage of the legislation governing electronic form of legal acts, especially electronic signatures and electronic records. The Author presents the possibility to satisfy the statutory requirements of a written form of contract by affixing an electronic document with various types of electronic signatures. The article also presents the rules of functioning of Public Key Infrastructure and certification service providers and their legal responsibility. 